\title{
COEFFICIENT FUNCTIONAL FOR THE KTH ROOT TRANSFORM OF ANALYTIC FUNCTION AND APPLICATIONS TO FRACTIONAL DERIVATIVES
}

\author{
T. PANIGRAHI AND S. K. MOHAPATRA
}

\begin{abstract}
In the present investigation, the authors introduce certain subclass of analytic function and obtain the sharp upper bounds for the coefficient functional $\left|b_{2 k+1}-v b_{k+1}^{2}\right|$ corresponding to the kth root transformation of certain normalized analytic function defined on the unit disk $\Delta$ in the complex plane. As an application of the main results, we obtain the Fekete-Szegö inequalities for the function defined by fractional derivatives. Similar problems are investigated for the inverse function of $f$ and for the function $\frac{z}{f(z)}$. Our results generalize and unify the work of earlier researchers in this direction.
\end{abstract}

Mathematics subject classification (2010): 30C45, 30C80.

Keywords and phrases: Analytic function, Fekete-Szegö inequality, kth root transformation, subordination, fractional derivatives.

\section{REFERENCES}

[1] O. P. Ahuja And M. JahAngiRi, Fekete-Szegö problem for a unified class of analytic functions, Panamer. Math. J. 7, 2 (1997), 67-78.

[2] R. M. Ali, S. K. Lee, V. Ravichandran and S. Supramaniam, The Fekete-Szegö coefficient functional for the transforms of analytic functions, Bull. Iranian Math. Soc. 35, 2 (2009), 119-142.

[3] R. M. Ali, V. Ravichandran AND N. Seerivasagan, Coefficient bounds for p-valent functions, Appl. Math. Comput. 187, 1 (2007), 35-46.

[4] S. Annamalai, C. Ramachandran and G. Murugusundaramoorthy, Fekete-Szegö coefficient for the Janowski $\alpha$-spirallike functions in open unit disk, Int. J. Math. Anal. 8, 19 (2014), 931-938.

[5] R. M. El-Ashwah, M. K. Aouf and F. M. Abdulkaren, Fekete-Szegö inequality for certain class of analytic function of complex order, Int. J. Open Problem Complex Anal. 6, 1 (2014), 12 pages.

[6] N. E. Cho And S. OwA, On the Fekete-Szegö problem for strongly a logarithmic quasi convex functions, Southeast Asian Bull. Math. 28, 3 (2004), 421-430.

[7] J. H. Choi, Y. C. Kim And T. Sugawa, A general approach to the Fekete-Szegö problem, J. Math. Soc. Japan 59, 3 (2007), 707-727.

[8] M. Darus and T. N. Shanmugam and S. Sivasubramanian, Fekete-Szegö inequality for a certain class of analytic functions, Mathematica 49, 72 (1) (2007), 29-94.

[9] M. DARUS AND N. TUNESKI, On the Fekete-Szegö problem for generalized close-to-convex functions, Int. Math. J. 4, 6 (2003), 561-568.

[10] M. FeKETE AND G. SZEGÖ, Eine bemerkung über ungerade schlichte funktionen, J. London Math. Soc. 8, (1933), 85-89.

[11] F. R. KeOGH And E. P. Merkes, A coefficient inequality for certain classes of analytic functions, Proc. Amer. Math. Soc. 20, (1969), 8-12.

[12] O. S. Kwon And N. E. CHO, On the Fekete-Szegö problem for certain analytic functions, J. Korea Soc. Math. Educ. Ser. B Pure Appl. Math. 10, 4 (2003), 265-271. 
[13] W. MA AND D. Minda, A unified treatment of some special classes of univalent functions, in: Proceeding of the Conference on Complex Analysis, Z. Li, F. Ren, L. Yang and S. Zhang (eds.), Int. Press (1994), 157-169.

[14] S. S. Miller And P. T. Mocanu, Differential Subordination: Theory and Applications, Series on Monographs and Textbooks in Pure and Applied Mathematics 225, Marcel Dekker, New York, 2000.

[15] S. OWA AND H. M. SRIVASTAVA, Univalent and starlike generalized hypergeometric functions, Canad. J. Math. 39, (1987), 1057-1077.

[16] T. Panigrahi and G. Murugusundaramoorthy, The Fekete-Szegö inequality for subclass of analytic function of complex order, Adv. Stud. Contemp. Math. 24, 1 (2014), 67-75.

[17] C. Ramachandran, S, Sivasubramanian and H. Silverman, Certain coefficient bounds for p-valent functions, Int. J. Math. Math. Sci. (2007), doi: 10:1155/2007/46576.

[18] V. Ravichandran, M. Darus, M. H. Khan and K. G. Subramanian, Fekete-Szegö inequality for certain class of analytic functions, Aust. J. Math. Anal. Appl. 1, 2 (2004), 4-7.

[19] V. RAVICHANDRAN, A. GANGADHARAN AND M. DARUS, Fekete-Szegö inequality for certain class of Bazillevic functions, Far East J. Math. Sci. 15, 2 (2004), 171-180.

[20] R. B. Sharma, M. HARIPRIYA AND K. SAROJA, A coefficient functional for the transformations of starlike and convex functions of complex order, Gen. Math. Notes 39, 2 (2015), 16-30. 